Board of Governors of the Federal Reserve System

International Finance Discussion Papers

Number 533

January 1996

\title{
REGIONAL PATTERNS IN THE LAW OF ONE PRICE: THE ROLES OF GEOGRAPHY VS. CURRENCIES
}

Charles Engel and John H. Rogers

NOTE: International Finance Discussion Papers are preliminary materials, circulated to stimulate discussion and critical comment. References in publications to International Finance Discussion Papers (other than an acknowledgement that the writer has had access to unpublished material) should be cleared with the author or authors. 


\begin{abstract}
We find evidence that the law of one price (LOOP) holds more nearly for country pairs that are within geographic regions than for country pairs that are not. These findings are established using disaggregated consumer price data from 23 countries (including data from eight North American cities.) We find that failures of LOOP are closely related to nominal exchange rate variability, suggesting a link to sticky nominal prices. We also find that distance can explain failures of LOOP, suggesting the failures arise from imperfect market integration. However, these two sources do not explain all of the failure of LOOP. We speculate that integrated marketing and distribution systems within regions cause LOOP to hold more nearly intraregionally. We present a formal model of marketing and distribution to illustrate this hypothesis.
\end{abstract}


Regional Patterns in the Law of One Price:

The Roles of Geography vs. Currencies

\section{Charles Engel and John H. Rogers ${ }^{1}$}

The failure of the law of one price has been a puzzle for economists at least since Isard's classic 1977 study. There has been renewed interest in this problem recently. A significant motivation for this resurgence of interest has been the apparently large misalignment of prices between the U.S. and other countries, most notably Japan. For example, in April 1995, according to The Economist, a Big Mac costs $\$ 2.32$ in the U.S. but the dollar price of a Big Mac in Japan was \$4.65. In June 1995, the cover price of an issue of The Economist was $\$ 3.50$ in the U. S., but the equivalent dollar price in Japan was $\$ 10.24$.

A related question in international trade has concerned the degree to which markets have become regionalized. That is, are goods markets more integrated within regions than across regions? That is the question Frankel, Stein and Wei (1994) address by examining the flow of goods between countries intraregionally and interregionally. They found that the claims that regional trading blocs are emerging are greatly exaggerated. We address this issue by examining whether price variability is smaller within regions than between

\footnotetext{
${ }^{1}$ Engel is a professor of economics at University of Washington and a Research Associate at the National Bureau of Economic Research. Rogers is an economist in the Division of International Finance, Board of Governors of the Federal Reserve System, and an assistant professor at Pennsylvania State University. This paper was prepared for the NBER conference on Regionalization in the World Economy. The authors thank Anthony Creane, Jeffrey Frankel, Ken Froot and Mike Knetter for useful comments and discussions. Part of the work on this project was completed while Engel was a Visiting Scholar at the Federal Reserve Bank of Kansas City and at the International Monetary Fund. The views expressed in this paper are those of the authors and do not necessarily represent the views of the Board of Governors of the Federal Reserve System or other members of its staff, the Federal Reserve Bank of Kansas City, or the International Monetary Fund. Engel also acknowledges assistance from the National Science Foundation, NSF grant \#SBR932078.
} 
regions.

A region might consist, for example, of the nations of the European Union, or the states of the United States. There are several reasons why there may be smaller price disparities intraregionally than interregionally. Most obviously, two locations within a region are usually closer together than two locations in different regions. The pricingto-market literature (see, for example, Dornbusch (1987), Krugman (1987), Froot and Klemperer (1989) and Knetter (1989)) has generally assumed that locations are completely separated, so that price discrimination is feasible, without any possibility of consumers arbitraging differences in final goods prices. Engel and Rogers (1995) have noted that while there is in practice little arbitrage undertaken to take advantage of differences in prices of consumer goods, at the intermediate goods level there are likely to be some constraints on the degree of price discrimination possible. The closer together two locations are, the less dispersion is likely in these intermediate goods prices. This in turn will reflect on the amount of cohesion in final goods prices. We would expect that the amount of price dispersion to be positively related to the distance between the locations.

Another reason why there may be less price variability intraregionally is that the nominal exchange rate between locations within a region is often fixed, or at least not very variable. Cities within the U.S. share a common currency; the exchange rate between Germany and the Netherlands has been virtually fixed for a number of years; and, the French franc has floated against the German mark within a narrow band under the exchange rate mechanism of the European Monetary System. If nominal prices are sticky in the currency of the country in which the final good is sold, then when the nominal exchange rate between two countries is highly volatile, the relative prices of similar goods across the two countries will be similarly volatile. On the other hand, when the exchange rate is quiescent, there is not much variance in relative prices. 
A third possible explanation for the importance of regions is that frequently countries in a region form free trade areas, customs unions or common markets. The absence of barriers to trade clearly could help to explain why the law of one price holds more nearly within regions.

Price dispersion may be smaller for countries within a region because pricediscriminating monopolists may charge similar mark-ups. The pricing-to-market literature has placed emphasis on how these mark-ups respond to changes in the exchange rate. We note that variation in mark-ups could account for fluctuations in prices of similar goods between locations. Within a region there may be smaller differences in demand elasticities across locations, so there may be little variation in mark-ups intraregionally.

The pricing-to-market literature focuses on the prices of exports. Our work examines consumer prices. One channel for price variation that would be important in retail prices, but not reflected in export prices, arises from the costs associated with distribution and marketing. If these costs vary from location to location, they can contribute to price dispersion. We shall argue that a distinguishing feature of locations within a region is that they share a unified distribution system for final goods. For example, if a nation-wide department store chain in the U.S. sells some product, many of the costs of bringing that good to market are not specific to the location in which the good is sold. Advertising, packaging, and services undertaken at the corporate headquarters are reflected in the final goods price, but are not a function of conditions in the retailing location. So, prices of goods distributed under a unified system share a significant common cost component.

Recent studies have amassed important new evidence on the nature of failures of the law of one price. The large empirical literature on pricing to market -- which examines export and import prices of very homogeneous products -- has recently been augmented by 
Knetter's (1994) study of pricing-to-market of German exports. Knetter concludes that German firms charge much higher prices to Japanese importers than to other markets, and, thus, pricing-to-market accounts in large part for the high Japanese retail prices. Engel (1993) examines the extent to which failures of the law of one price can explain real exchange rate movements. He finds that the relative prices of similar goods across countries have much greater variance than relative prices of different goods within a country. Rogers and Jenkins (1995) reach similar conclusions regarding the degree of persistence of shocks to relative prices. Engel and Rogers (1995) find that the dispersion of prices of similar goods between cities in Canada and the U.S. is greater the farther apart the cities are. This evidence favors the notion that price discrimination can account for price differences between locations. But, they find that the variance is much greater for cities that lie in different countries compared to equidistant cities in the same country. This indicates that marketing costs or price stickiness are important.

Ghosh and Wolf (1994), examining the cover price of The Economist, find evidence in favor of the sticky price story as opposed to pricing-to-market. They find that the time pattern of price adjustment is consistent with a menu cost explanation ofprice adjustment. Froot, Kim and Rogoff (1995) examine several centuries ofdata on individual goods prices of commodities in England and Holland. They find that the degree of persistence of deviations from the law of one price has not changed much over the centuries, suggesting that nominal exchange rate volatility cannot be accounting for all of the failure. Cumby (1993) finds that in fact there is fairly rapid convergence to the law of one price for Big Macs during the floating rate period: $70 \%$ of the price gap across countries disappears within a year,

Here, we explore further the notions that pricing-to-market and nominal price stickiness matter for the failures of the law of one price. The basic notion of this 
paper is that the degree of failure of the law of one price for goods sold in two different locations will depend on the distance between those locations if price discrimination is significant. However, to the degree that nominal price stickiness is important, then prices of similar goods will exhibit more variance between countries the greater is the variation in the nominal exchange rate of those two countries' currency. So, using price data on individual goods from dozens of countries, we relate the variation in prices of similar goods across countries to the distance between those countries, and the variance of their nominal exchange rates. ${ }^{2}$

But, as we have noted, we pay special attention to the variability of prices within regions. If the mark-ups are more similar within regions, or if the distribution system is more homogenized, then we expect that price dispersion will be lower for pairs of countries located within regions.

In the next section of the paper, we review some of the standard explanations for the failure of the law of one price. We discuss how market segmentation and price discrimination can lead to failures, and the role of sticky nominal prices. Our story about unified distribution systems within a region is less familiar, so we lay out a simple model and explore its implications.

Then, we proceed to examination of the data. First, we describe the data on goods prices and provide some summary statistics. The remainder of the paper is concerned with the regressions relating price variability to distance and other geographic factors, exchange rate variability, measures of trade barriers and regional variables.

2 Wei and Parsley (1995), in a work done simultaneously and independently, address many of the issues we do. However, their main focus is on the convergence to PPP. 
When the law of one price fails between two locations, there is evidence that the markets are not completely integrated. One of the most direct implications of rational behavior is that two identical goods selling in the same market should have the same price.

Clearly one reason that prices may not be equalized is that there is some cost to shipping goods between locations. Even prices of such homogeneous and durable goods as copper, for which international commodity markets are well-established, have some price variation across locations, When goods arecostly to transport, then arbitrage may not fully equalize prices.

If transportation costs are sufficiently high, then no arbitrage takes place. That is the assumption implicit in much of the "pricing-to-market", or exchange-rate "passthrough" literature. In fact, there seems to be very little evidence of arbitrage in final goods beyond a few well-known anecdotes. For example, we know that shopping malls appeared on the northern border of the U.S. at a time when many prices of consumer goods were lower in the U.S. than they were in Canada (when prices were expressed in a common currency. ) More recently, before the peso devaluation in late 1994, similar outlets opened on the U.S. side of its southern border. At times it has been relatively easy for consumers to import luxury German cars directly from Germany, rather than buying them from a U.S. dealer. And, there is the famous puzzle that for some consumer products, Japanese find it cheaper to fly to the U.S. and buy the goods from American retailers than to buy them at Japanese outlets. However, all of these practices are small relative to the total volume of trade.

But, the dearth of opportunities for arbitrage in final goods undoubtedly masks the constraints that international trade places on final goods prices. As Engel and Rogers 
(1995) note, the final good purchased by consumers is really a joint product -- the actual good itself, and the retailing services that bring the good to market. We can think of the physical good as an intermediate good, with price q, that is an input into the final consumer good. Suppose there were iceberg transportation costs, so that only a fraction of the good, $\delta$, remained after the good is shipped to a foreign country. Arbitrage insures that $\mathrm{q} \leq \mathrm{q}^{*} / \delta$, where $\mathrm{q}^{*}$ is the price of the intermediate good in the foreign country. If this relationship did not hold, arbitrageurs would export the good from the home to the foreign country, which would tend to drive up prices domestically and down abroad. Similarly, we must have $\delta q^{*} \leq \mathrm{q}$, lest arbitrageurs export goods from the foreign country to the home. So, fluctuations in the relative price of the intermediate good inthetwo goods are constrained within bands: $\delta \leq \mathrm{q} / \mathrm{q}^{*} \leq 1 / \sim$.

Tariffs or other barriers to trade act much like transportation costs in creating wedges between prices of traded goods indifferent locations. Suppose that the foreign country puts an ad valorem tariff of $\tau^{*}$ on imports from the domestic country. Then, arbitrage guarantees only $\mathrm{q}^{*} \leq\left(1+\tau^{*}\right) \mathrm{q}$. Likewise, if $\tau$ is the tariff rate imposed by the domestic country, $\mathrm{q} \leq(1+\tau) \mathrm{q}^{*}$. So, the relative price can fluctuate $\mathrm{q} / \mathrm{q}^{*}$ can fluctuate in the range from $1 /\left(1+\tau^{*}\right)$ to $1+\tau$.

The distribution and marketing services contribute to the cost of the final good, If the good were sold in competitive markets, the price of the good is greater than $q$ by an amount equal to the value of the marginal product of the factors providing the distribution and marketing services. Even if the intermediate product were to have the same price in the two locations, the retail price could differ because non-traded inputs go into marketing. Sanyal and Jones (1982) present a general equilibrium model that has this structure -- no final goods are traded, but all consumer goods contain an intermediate traded component which they call a "middle product". As returns to the nontraded inputs into marketing vary over time, there will be variation in the final goods 
prices between locations.

If final goods could be traded costlessly, then taxes (other than trade taxes) should not contribute to differences in prices between locations. Gasoline sells for the same price on either side of State Line Road, which separates Kansas City, Kansas from Kansas City, Missouri, in spite of the fact that gasoline taxes are different in the two states. But, if the final product is not traded, then both taxes levied on producers and consumers may cause prices to differ between locations. These would cause differences in prices in exactly the same way as returns to non-traded factors used in marketing and distribution: variation over time in taxes can lead to variation over time in relative final goods prices.

It is probably not accurate to describe most consumer goods markets as competitive. If there is some monopoly in the final goods market, then the price may exceed marginal cost. Inmost models of imperfect competition, thesize of the mark-up is inversely related to the elasticity of demand for the product. The elasticity of demand may be different in different locations, and may vary over time, both because tastes are different (and changing) and because the elasticity of demand may change as we move along a given demand curve.

We note that our empirical work detects movement in the prices of similar goods in different locations. If prices were nonequalized, but the discrepancy were constant, it would not show up in our data. We can conclude that deviations from the law of one price of the type we detect can be attributed to: (1) the wedge in the price of traded intermediate goods that arises from transportation costs or from trade taxes; or, (2) variation in the prices of non-traded inputs into distribution, in consumer and producer taxes and in the mark-up over marginal costs. Constant ad valorem tariffs or iceberg transportation costs allows variation in the relative prices between locations. However, the differences in prices of non-traded inputs, consumer or producer taxes, or mark-ups 
across locations need to change over time to account for variation in relative prices.

One other explanation for failures of the law of one price that vary over time arises when final goods prices are set in the currency of the location where the good is sold. If these prices are pre-set, and thus do not respond rapidly to shocks, then the prices between locations will change if they are expressed in a common currency and the nominal exchange rate varies. Floating exchange rates have been very volatile -- much more volatile than aggregate price levels at the least (see Mussa (1986)), so the stickyprice theory seems a natural path to explore. A complete theory of sticky nominal prices would take into account some of the factors we have already noted.

For example, consider a menu-cost model of the type proposed by Mankiw (1985). When there is an infinitesimal shock to demand, the loss in profits from not adjusting prices in that model is second-order. For a small but finite shock to demand, there is a loss in profits if the price is not adjusted optimally. However, if there is a small menu cost, then non-adjustment may be optimal. The size of menu costs needed to make sticky prices optimal depends on the elasticity of demand. If demand were perfectly elastic, as in competitive markets, then the firm loses all of its sales if it does not adjust prices. The more inelastic is demand, the smaller the loss from non-adjustment.

In the international context, distance between locations could contribute to price stickiness. The more isolated a country is, the fewer foreign competitors it will have. U.S. car manufacturers are less vulnerable to imports of German cars than are French producers, because of transport costs. When a firm faces fewer competitors, the elasticity of demand for its product will be lower, thus increasing the likelihood of nominal price stickiness.

In the introductory remarks, we noted that two countries within a region may have a higher correlation of prices of similar goods for a number of reasons. Distance is smaller, trade barriers are lower, demand elasticities (and, hence mark-ups) may be more 
similar, and their nominal exchange rate may be less variable. These effects are familiar. In the next section, we advance a theory based on distribution costs. Locations in a region may share a common distribution system.

\section{Distribution Costs and Regions}

A. Prices within a Region

A model in which intermediate goods are traded, but final goods are sold only to domestic consumers by a monopolistic distributor captures the essential features described in the previous section. Prices differ between locations because of locationspecific costs of marketing, and because of differences across locations in the mark-up by the monopolist.

Not all marketing costs are local. Corporations often set up distribution networks to many locations. The distribution entails freed costs which are not specific to the point where the good is sold. For example, advertising campaigns generally entail significant up-front costs which are large relative to the local costs. The services performed at corporate headquarters -- accounting, legal, mamgement, etc. -- are not location specific. Packaging and assembly often occurs at a single plant, with the final product distributed to many locations.

Our definition of "region" is a group of locations that share a distribution system. This region may consist of cities in one country or a part of a country, or a group of countries. Indeed, a set of locations may be a region for some goods while for other goods it is not.

Our definition of region stems in part from our earlier work (Engel and Rogers (1995)). There we investigated the dispersion of prices of similar goods among 23 cities in Canada and the U.S. We found that distance between locations was important in 
explaining the range of fluctuations of prices between city pairs. However, taking distance into account, there was much more dispersion between city pairs that lay on opposite sides of the national border than for city pairs within either country. One explanation for this finding is that prices are sticky in terms of the currency of the country that the good is sold in. Because the exchange rate was floating between these two countries, the relative prices between cross-border city pairs would fluctuate as the exchange rate changed.

However, we found that the sticky-price story cannot account for more than half of the border effect. We can measure relative prices between locations without taking the exchange rate into account. For example, we can take the price of food in Toronto relative to the overall CPI in Toronto, and compare that to the price of food in Chicago relative to the overall CPI in Chicago. There is a significant border effect even when using these relative-relative prices. That is, relative-relative prices among crossborder city pairs are still much more variable than relative-relative prices for intranational city pairs, taking into account distance effects. One cannot attribute this finding to sticky prices and floating exchange rates, since the exchange rate is not used in the calculation of prices. Although we do not pinpoint the source of this border effect, a plausible explanation is that there is more integration of the distribution and marketing systems for cities within each country than there is across countries.

Our model consists of two small countries in general equilibrium. We consider two cases, When intermediate goods are traded, but not final goods which require marketing inputs, then the two countries are not members of a region. When the two countries share a marketing system so that all final goods can be traded between themselves, but not with the rest of the world, they are in a region, To keep matters simple, we eliminate all of the complications discussed in section 1 -- transportation costs, tariffs and taxes, sticky prices, etc. Furthermore, when we consider two countries within a region, we 
assume an exporter bears no marketing costs that are local in the importing country.

We first consider the model with no "region".

There are four goods. A unit of good $\mathrm{z}$, which is the numeraire, is produced with one unit of labor in all countries -- home, abroad, and in the world economy. This good is consumed by individuals, and does not require any marketing. It can be thought of as a simple, homogeneous product such as fuel oil. Engel (1993) finds that even for consumer prices, the failure of the law of one price is not too large for such products.

Good $\mathrm{x}$ also requires a fixed labor input. Its price in the world economy is $\mathrm{p}_{\mathrm{x}}$. The required labor input for good $\mathrm{x}$ may differ in the home country and the foreign country, and in each country this may differ from $\mathrm{p}_{\mathrm{x}}$. There is a fixed supply of labor at home and abroad. In each country that labor force will be devoted entirely to the production of good $\mathrm{x}$ or good $\mathrm{z}$, depending on the pattern of comparative advantages Each country acquires the good it does not produce through international trade, either with the other small country or with the rest of the world.

So, let L be the labor supply in the domestic country. If the country produces $\operatorname{good} \mathrm{z}$, then $\mathrm{L}-\mathrm{z}$ is the amount of exports of $\operatorname{good} \mathrm{z}$, and we have

$$
L-Z=p_{x} x .
$$

If the country produces good $\mathrm{x}$, its exports are $\mathrm{L}-\mathrm{p}_{\mathbf{x}} \mathbf{x}$ and its imports are $\mathrm{z}$.

There are also two final goods which require marketing. For concreteness, think of the two goods as McDonald's hamburgers (good 1) and Wimpy's hamburgers (good 2). Consumers in each of the domestic and foreign countries get utility from consumption of both goods. However, both goods are not necessarily marketed in each country.

Both goods use $\mathrm{x}$ as an intermediate input. For now, we concentrate on the home country. Output of goods 1 and 2 is determined by the production functions: good $x$ equals $p_{\mathbf{x}}$. 


$$
\begin{aligned}
& y_{1}=\gamma x_{1}-a, \\
& y_{2}=\eta x_{2}-b .
\end{aligned}
$$

The marginal costs in units of good $\mathrm{x}$ of marketing goods 1 and 2 respectively are $1 / \gamma$ and $1 / \eta$. These costs may bedifferent in the foreign country. The fixed costs of marketing -- $a$ and $b$-- may also be different in the foreign country.

When the two small countries are not in a region, goods 1 and 2 are not traded. Consumers must buy these goods from local producers.

The representative consumer maximizes

$$
U=\frac{\alpha}{1-\phi} c_{1}^{1-\phi}+\frac{\beta}{1-\phi} c_{2}^{1-\phi}+c_{z}, \quad 0<\phi<1,
$$

subject to the constraint

$$
\Pi+\mathrm{L}=\mathrm{p}_{1} \mathrm{c}_{1}+\mathrm{p}_{2} \mathrm{c}_{2}+\mathrm{c}_{\mathrm{z}},
$$

The representative consumer owns shares in the firms which produce goods 1 and2. It takes the profits from these firms as given. The sum of the profits the consumer receives from these firms is 11 .

Demand for each good is given by:

$$
\begin{aligned}
& c,=\left(p_{1} / \alpha\right)^{-1 / \phi}, \\
& c_{2}=\left(p_{2} / \beta\right)^{-1 / \phi}, \text { and } \\
& C^{*}=\Pi+L-C_{1}-c_{2} .
\end{aligned}
$$

We assume that $\mathrm{L}$ is so large that consumption of $\mathrm{z}$ is always positive. Note that the elasticity of substitution between $c_{1}$ and $c_{2}$, as well as the elasticity of demand for $c_{1}$ and $C_{2}$ with respect to $p_{1}$ and $p_{2}$ respectively, are given by $1 / \phi$. If, in equilibrium, either good 1 or good 2 is not produced, then its demand is zero, but the demand for the other goods is as given.

The monopolists that produce goods 1 and 2 set prices to maximize profits given by:

$$
\begin{aligned}
& \Pi_{1}=p_{1} y_{1}-p_{x} x_{1}, \text { subject to } y_{1}=c_{1}, \\
& \Pi_{2}=p_{2} y_{2}-p_{x} x_{2}, \text { subject to } y_{2}=c_{2} .
\end{aligned}
$$


The optimal prices are mark-ups over marginal costs:

$$
\begin{aligned}
& p_{1}=\frac{p_{x}}{\gamma(1-\phi)}, \\
& p_{2}=\frac{p_{x}}{\eta(1-\phi)} .
\end{aligned}
$$

If, at these prices, one or both firms' profits are negative, the firm chooses not to produce at all. (The fixed costs -- $\mathrm{a}$ and $\mathrm{b}--$ are not sunk costs.)

The equilibrium condition for the economy,

$$
\mathrm{p}_{\mathrm{x}} \mathrm{x}+\mathrm{z}=\mathrm{p}_{\mathrm{x}}\left(\mathrm{x}_{1}+\mathrm{x}_{2}\right)+\mathrm{c}_{\mathrm{z}} \text {, }
$$

is equivalent to the representative consumer's budget constraint, with $\pi=\pi_{1}+\pi_{2}$.

If both Wimpy's and McDonald's hamburgers are sold in the home country, the exact price index for hamburgers, $\mathrm{p}$, is givenby

$$
\begin{aligned}
\mathrm{p} & =\left[\omega \mathrm{p}_{1}^{(\phi-1) / \phi}+(1-\omega) \mathrm{p}_{2}^{(\phi-1) / \phi}\right]^{\phi /(\phi-1)} \\
& =\frac{\mathrm{p}_{\mathrm{x}}}{1-\phi}\left[\omega \gamma^{(\phi-1) / \phi}+(1-\omega) \eta^{(\phi-1) / \phi}\right)^{\phi /(\phi-1)},
\end{aligned}
$$

where the weight that good 1 receives in the index, $\omega$, is given by

$$
\omega=\frac{\alpha^{1 / \phi}}{\alpha^{1 / \phi}+\beta^{1 / \phi}}
$$

Of course, if only one of the burgers is sold in the home country, the burger price index is simply the price of that burger.

The set-up is the same in the foreign country, but any of the taste or technology parameters may be different than in the home country. We have:

$$
\begin{aligned}
& \mathrm{p}_{1}^{*}=\frac{\mathrm{p}_{\mathrm{x}}}{\gamma^{*}\left(1-\phi^{*}\right)}, \\
& \mathrm{p}_{2}^{*}=\frac{\mathrm{p}_{\mathrm{x}}}{\eta^{*}\left(1-\phi^{*}\right)},
\end{aligned}
$$

if both goods are produced.

There are a large number of cases to consider when the countries are not part of a region, but we will focus on one in which only MacDonald's burgers are sold in the home 
country and only Wimpy's burgers are sold in the foreign country. In other words, in the home country, the fixed cost a is low enough so that good 1 is profitable, but $b$, the fixed cost for good 2, is too high for that firm to make profits. The situation is reversed in the foreign country. So, $\mathrm{p}=\mathrm{p}_{1}$ and $\mathrm{p}^{*}=\mathrm{p}_{2}^{*}$.

In this case, there are two reasons why hamburger prices could be different at home and abroad -- the marginal cost of distribution could be different ( $1 / \gamma$ versus $\left.1 / \eta^{*}\right)$, and the mark-up could differ ( $\frac{1}{1-\phi}$ versus $\left.\frac{1}{1-\phi^{*}}\right)$.

Now, compare this to the case in which the two countries are in a region. For simplicity, we consider a world in which McDonald's in the home country is licensed to sell McDonald's hamburgers in both countries (so that the foreign producer of McDomld's is ruled out of the market) and the foreign Wimpy's is licensed to sell Wimpy's burgers in both countries. Alternatively, we could think of this as being the case in which the fixed costs b and a" are so high that firm 2 at home and firm 1 abroad would never find it profitable to sell burgers.

Each producer can price discriminate, since they are the only ones with the distribution facilities to sell their burgers in both countries. So, McDonald's will set prices as

$$
\mathrm{p}_{1}=\frac{\mathrm{p}_{\mathrm{x}}}{\gamma(1-\phi)} \text {, and } \mathrm{p}_{1}^{*}=\frac{\mathrm{p}_{\mathrm{x}}}{\gamma\left(1-\phi^{*}\right)} .
$$

Wimpy's prices will be

$$
\mathrm{p}_{2}=\frac{\mathrm{p}_{\mathrm{x}}}{\eta^{*}(1-\phi)}, \text { and } \mathrm{p}_{2}^{*}=\frac{\mathrm{p}_{\mathrm{x}}}{7 /(1-@ *)^{*}},
$$

Note that if $\phi=\phi^{*}$, then prices of both burgers are the same at home and abroad.

Even if $\phi=\phi^{*}$, the burger price indexes need not be identical. Home country residents, for example, might have a preference for McDonald's hamburgers, so $\omega>\omega^{*}$. However, under these assumptions, it is easy to show that $\left(\mathrm{p} / \mathrm{p}^{*}\right)_{\mathbb{R}}$, the ratio of the price 
indexes if these two countries were in a region, is closer to unity than $\mathbf{p}_{1} / \mathrm{p}_{2}^{*}$, which would be the ratio of the price indexes if the two countries were not in a region. ${ }^{4}$ This means that the range of fluctuation of the relative burger price indexes would be smaller for two countries that are in the same region.

However, if the elasticities of demand in the two countries are sufficiently different, so that the difference in the mark-ups is large, it is possible that the burger price index could fluctuate even more for two countries that are in the same region than for countries that are not in the same region. This theoretical possibility seems unlikely to occur in practice, however, because it requires large differences in tastes between residents in the two locations.

The utility function in this section is separable in consumption of goods 1 and 2. This results in a demand curve for good 1 that does not depend on $\mathrm{P}_{2}$, and likewise for good 2. This rules out an important case which the next section discusses: that McDonald's could drive out Wimpy's (or vice-versa) if the two countries are in a region. In the model of this section, regionalization might cause the burger price indexes in the two locations to be more nearly equal because it leads to a diffusion of products across the regions. Wimpy's and McDonald's are consumed in both regions after regionalization, so the burger price indexes are weighted averages of both burger prices in both locations. In the model of the next section, regionalization leads to harmonization of burger prices simply because one burger firm becomes dominant and drives out the other. Everybody in both locations ends up eating only McDonald's burgers.

Before turning to that model, we close out the model of a country within a region by noting the equilibrium conditions for the home country, which produces good 1. Profits for industry 1 are given by Appendix 2.

This proposition and the one discussed in the next paragraph are demonstrated in 


$$
1-r,=p_{1} y_{1}-p_{x} x_{1}
$$

The budget constraint for individuals is given by:

$$
\Pi_{1}+\mathrm{L}=\mathrm{p}_{1} \mathrm{c}_{1}+\mathrm{p}_{2} \mathrm{c}_{2}+\mathrm{z}
$$

Combining these two yields the trade balance condition, with exports on the left-handside (assuming the country exports good $\mathrm{x}$ as well as good 1 ):

$$
\mathrm{p}_{1}\left(\mathrm{y}_{1}-\mathrm{c}_{1}\right)+\mathrm{L}-\mathrm{p}_{\mathrm{x}} \mathrm{x}_{1}=\mathrm{z}+\mathrm{p}_{2} \mathrm{c}_{2}
$$

\section{B. Can Regionalization Reduce Variety?}

In this section, we consider a world in which consumers may switch from Wimpy's burgers to McDonald's burgers if the price of McDonald's burgers were low enough. When the two countries are isolated, Wimpy's could exist in one and McDonald's in the other. But, if firms are able to extend their distribution system across both countries, we may find that the firm that is most efficient at marketing drives out its competitor, even when the goods are not identical. What we are describing, of course, is the homogenization of consumer products across countries that any world traveller will have noticed.

The model presented here is highly parameterized, because what we wish to show is that for some parameter values, McDonald's might drive Wimpy's out. We will first consider the equilibrium when the two countries are in a region so that final goods can be marketed in both countries, and show how only McDonald's may sell burgers. Then, we show that if the two countries were not members of a region, Wimpy's might be sold in one of the countries.

Consumers in both countries have the same preferences. In the home country, they maximize

$$
\mathrm{u}=\ln \left(2 \mathrm{c}_{1}^{1 / 2}+2 \mathrm{c}_{2}^{1 / 2}\right)+\mathrm{z}
$$


If both goods 1 and 2 are sold in the market, the demand by a typical consumer is:

$$
\begin{aligned}
& c_{1}=\frac{p_{2}}{2 p_{1}\left(p_{1}+p_{2}\right)} . \\
& c_{2}=\frac{p_{1}}{2 p_{2}\left(p_{1}+p_{2}\right)} .
\end{aligned}
$$

We assume that world population is 2 , so, letting a - represent world demand, we have $\tilde{c}_{1}$ $=2 \mathrm{c}_{1}$ and $\tilde{\mathrm{c}}_{2}=2 \mathrm{C}_{2}$.

Suppose one of the goods, good2, is not sold. Then demand for good 1 is given by $c_{1}=\frac{1}{2 \mathrm{p}_{1}}$,

and $\tilde{c}_{1}=I / p_{1}$.

Firm 1 in the home country can produce McDomld's burgers according to $\mathrm{y}_{1}=\mathrm{x}_{1}-\mathrm{a}$.

Firm 2 in the foreign country can produce Wimpy's burgers with the production function: $\mathrm{y}_{2}^{*}=\mathrm{x}_{2}^{*}-\mathrm{b}^{*}$.

We will assume that $\mathrm{b}$ and $\mathrm{a}^{*}$ are so high that there are no competitors to these two monopolists that sell the same type of burger. Of course, they compete with each other, since the demand for one's burger depends on the price of the other's.

For notational convenience, we will drop the * when denoting firm 2's price and output.

Firms 1 and 2 are nearly symmetric. They face symmetric demand curves, and they have the same marginal cost of production. The only difference is that their fixed costs could differ. We will assume that McDonald's has the lower fixed costs, so $a<b^{*}$.

The fixed costs are not sunk costs, so if the firm decides not to produce, it does not bear any costs. Still, it is helpful first to calculate the equilibrium prices and profits if the costs were sunk as a step toward finding the full equilibrium. So, we will use the superscript SC (for sunk costs) to denote prices and profits from this 
Bertrand equilibrium.

We shall see that in this equilibrium, both firms choose to produce if they ignore fixed costs. Hence, each firm faces the demand curve derived under the assumption that both goods are produced.

From the first-order condition for firm 1, taking firm 2's prices as given, we have

For firm 2, we have:

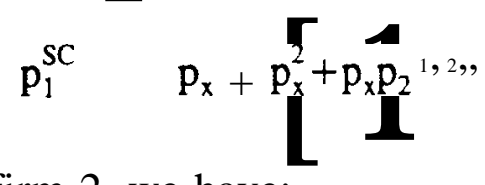

$$
\mathrm{p}_{2}^{\mathrm{sC}}, \quad \mathrm{p}_{\mathrm{x}}+\left[\mathrm{p}_{\mathrm{x}}^{2}+\mathrm{p}_{\mathrm{x}} \mathrm{p}_{1}^{1 / 2} .\right.
$$

Solving these two equations, we get

$$
\mathrm{p}_{1}^{\mathrm{SC}}=\mathrm{p}_{2}^{\mathrm{SC}}=3 \mathrm{p}_{\mathrm{x}} \text {. }
$$

Profits for firm 1 are given by

$$
\Pi_{1}^{S C}=p_{1}^{S C} \tilde{c}_{1}-p_{x} x_{1}=3 p_{x} \tilde{c}_{1}-p_{x}\left(\tilde{c}_{1}+a\right)=2 p_{x} F,-p p .
$$

We see that firm 1 chooses to produce at this price if it is ignoring fixed costs, since its profits exceed $-p_{x} a$. Using the fact that $p_{1}^{S C}=p_{2}^{S C}=3 p_{x}$, we can solve out for $c_{1}$ and calculate

$$
\Pi_{1}^{S C}=\frac{1}{3}-p_{x} a .
$$

Parallel computations show

$$
\Pi_{2}^{S C}=\frac{1}{3}-p_{x} b^{*}
$$

so, ignoring fixed costs, firm 2 also decides to produce.

Firm 1 might want to set its price lower than $\mathrm{p}_{1}^{\mathrm{SC}}$, however. If it set its price low enough, demand for firm 2's product may fall so low that firm 2 would not make a profit if it does take into account its fixed costs. If firm 2 decides not to compete, then firm 1 has captured the entire market. Its demand will be higher and its profits may be higher than when it sets its price at $\mathbf{p}_{1}^{\mathrm{sC}}$. 
Specifically, if firm 1 has captured the entire market, then its revenues are unity irrespective of the price it charges, since plcl $=1$ in that case. If firm 1 had the whole market to itself with no threat of entry by firm 2, it would produce arbitrarily close to zero and charge an arbitrarily high price. However, because firm 2 is a potential entrant, it will set a price just low enough so that firm 2's profits are zero. If its profits in that case are greater than $\Pi_{1}^{\mathrm{SC}}$, then that is the equilibrium.

We will use the superscript LP (for limit pricing) to denote equilibrium prices and profits in this case. Three conditions must hold for there to be a LP equilibrium. First, firm 1's profits must be greater than under the SC equilibrium. We have

$$
\pi_{1}^{\mathrm{LP}}=\mathrm{p}_{1}^{\mathrm{LP}} \tilde{\mathrm{c}}_{1}-\mathrm{p}_{\mathrm{x}} \mathrm{x}_{1}=1-\mathrm{p}_{\mathrm{x}}\left(\tilde{\mathrm{c}}_{1}+\mathrm{a}\right)=1-\frac{\mathrm{p}_{\mathrm{x}}}{\mathrm{p}_{1}}-\mathrm{p}_{\mathrm{x}} \mathrm{a} .
$$

So, for $\Pi_{1}^{L P}>\Pi_{1}^{S C}$, we need

$$
\mathrm{p}_{1}^{\mathrm{LP}}>\frac{3}{2} \mathrm{p}_{\mathrm{x}} \text {. }
$$

The second condition is that at $\mathrm{p}_{1}^{\mathrm{LP}}$, firm 2 's profits are just zero. Note that the best that firm 2 can do is set its price as above, according to

$$
\mathrm{P} 2=\mathrm{p}_{\mathrm{x}}+\left(\mathrm{p}_{\mathrm{x}}^{2}+\mathrm{p}_{\mathrm{x}} \mathrm{p}_{1}\right)^{1 / 2} \mathrm{~s}
$$

Firm 2 cannot price firm 1 out of the market since its fixed costs are higher than firm 1 's. So, firm 1 sets $\mathrm{p}_{1}$ so that

$$
\left(\mathrm{p}_{2}-\mathrm{p}_{\mathrm{x}}\right) \cdot \frac{\mathrm{PI}}{\mathrm{p}_{2}\left(\mathrm{p}_{1}+\mathrm{p}_{2}\right)}-\mathrm{p}_{\mathrm{x}} \mathrm{b}^{*}=\mathrm{O} \text {. }
$$

If $\mathrm{p}_{\mathrm{x}} \mathrm{b}^{*}$ is sufficiently high (greater than .2251),5 then a value for $\mathrm{p}_{1}^{\mathrm{LP}}$ exists which satisfies the first two conditions.

For $\mathrm{p}_{\mathrm{x}} \mathrm{b}^{*}=.2251, \mathrm{p}_{1}^{\mathrm{LP}}=\frac{3}{2} \mathrm{p}_{\mathrm{x}}$, and firm 1 is just indifferent between setting $\mathrm{p}_{1}$ at $\frac{3}{2} p_{x}$ and setting it at $3 p_{x}$.

5 Or, more exactly, $3 \& / \overrightarrow{0} \sqrt{2}+7 \sqrt{5}$. 
For $\mathrm{p}_{\mathrm{x}} \mathrm{b}^{*}<.2251$, firm 1 and firm 2 set prices at $3 \mathrm{p}_{\mathrm{x}}$. Both firms produce and they both make profits in this case, since $\mathrm{p}_{\mathrm{x}} \mathrm{a}<\mathrm{p}_{\mathrm{x}} \mathrm{b}^{*}<1 / 3$.

The third condition for a LP equilibrium is simply that at the value of $\mathrm{p}_{1}^{\mathrm{LP}}$ that satisfies the first two conditions, $\pi_{1}^{\mathrm{LP}}$ be positive. If the fixed cost, $\mathrm{a}$, is sufficiently low, this condition is satisfied. (For example, it is always satisfied if a ( o.)

So, if $\mathrm{p}_{\mathrm{x}} \mathrm{b}^{*}>.2251$ and $\mathrm{a}$ is sufficiently low, McDonald's will price Wimpy's out of the market if the two countries are in the same region.

Regionalization means that Wimpy's may not produce. Regionalization might mean the number of brands declines, if in fact Wimpy's would have produced were it just serving the foreign market. It is easy to produce an equilibrium under which $\mathbf{p}_{\mathbf{x}} \mathbf{b}^{*}>.2251$, but Wimpy's sells burgers in the foreign country if it is isolated from the home country. For example, if fixed costs for the potential firm 1 in the foreign country are very high, so that $\mathbf{p}_{\mathbf{x}} \mathbf{a}^{*}$ is large, then firm 2 in the foreign country would set its price just low enough to keep firm 1 from entering. If firm 1 is kept out of the market, then, when country 2 is in isolation and has a population of one, $\mathrm{p}_{2}^{*} \mathrm{c}_{2}^{*}=1 / 2$, so that firm 2 's revenue does not depend on its output. With $\mathrm{p}_{\mathrm{x}} \mathrm{a}^{*}$ sufficiently large, $\mathrm{p}_{2}^{*}$ could be so high and $c_{2}^{*}$ so low, that $\pi_{2}^{*}=p_{2}^{*} c_{2}^{*}-p_{x} x_{2}^{*}=1 / 2-p_{x}\left(c_{2}^{*}+b^{*}\right)$ would be positive.

The implications of this example for hamburger prices are straightforward. If the two countries are not in the same region, their burger prices are different. Indeed, they do not even sell the same type of burger. But, if the countries become regionalized, only one type of burger is marketed in the region -- in this example, at the same price in both countries. 


\section{Empirical Findings}

We investigate the behavior of final goods prices for 8 goods (plus the aggregate CPIs) measured in as many as 23 countries and 8 North American cities. We investigate the determinants of failures of the law of one price between the locations.

Our data are monthly price indexes for the overall CPI and sub-categories of the CPI such as food, fuel, etc. The data are described in detail in Appendix 1. For each good $i$, and for each pair of locations $j k$, we construct relative price, $q_{j k}^{i}$. Naturally, when the prices are from different countries, we use the nominal exchange rate to express prices in a common currency in constructing $q_{j k}^{i}$. Because our data are indexes and not actual prices, the level of $q_{j k}^{1}$ does not reveal anything about whether the law of one price holds or not. However, ifthe law of one price holds closely, therq ' would not vary much over time. Our measure of the magnitude of failures of the law of one price is a measure of the volatility of $\mathrm{q}_{\mathrm{jk}}^{\mathrm{i}}$ : the standard deviation of the firstdifference of this series.

The coverage of our price data varies from good to good. We have sufficiently long time series for the aggregate CPI for 29 locations. For the individual goods, our country coverage ranges from 29 locations for food prices down to 14 locations for health and recreation prices. If $\mathrm{N}$ is the number of locations, then we have $\mathrm{N}(\mathrm{N}-1) / 2$ location pairs.

While our data is both time-series and cross-section, the only use we make of the time series is to calculate the measure of volatility forq $q_{\mathbf{j k}}^{i}$. Once we have those measures in hand, we proceed to a cross-sectional analysis that attempts to explain differences in the volatility of $q_{j k}^{i}$ etween locations according to characteristics of the location pair $\mathbf{j k}$.

We focus on four explanatory variables: distance, the volatility of the nominal 
exchange rate, trade barriers, and regional groupings. Our basic empirical work regresses the standard deviation of changes in $\mathrm{q}_{\mathrm{jk}}^{\mathrm{i}}$ on measures of these four variables.

Table 1 contains some summary statistics. The top two lines of the table present the average standard deviation of $\mathrm{q}_{\mathrm{jk}}^{\mathrm{i}}$ for pairs of locations that are in selected regions. Note that not all location pairs in our sample would be included in one of these regions because many pairs lie in different regions.

These first two lines reveal a fairly strong correlation between the standard deviation of nominal exchange rates andthe standard deviation of $\mathrm{q}_{\mathrm{jk}}^{\mathrm{i}}$. Both series have low volatility for country pairings within the European Community, or within Europe more broadly defined, as well as for city pairs in the U.S. and Canada. On the other hand, Asian country pairs, and location pairs in North America when Mexico is included have relatively high nominal exchange rate and relative price variability.

The next eight rows in Table 1 report the average volatility for each of our eight goods for regional location pairs. We note that there are some large differences in the degree of volatility across the goods, but there still seems to be an overall correlation with the volatility of the nominal exchange rate.

The next set of numbers in Table 1 calculate the volatility of "relative relative" prices. We will discuss the significance of these numbers below.

The final row of Table 1 reports the average distance for location pairs within a region. There are two things worth noting here. First, while the European country pairs tend to have the lowest relative price volatility, they also are quite close -- an average of only 651 miles apart. Second, the average distance between all of our location pairs is 3887 miles. Note that location pairs within regions tend to be much closer on average than this.

In Table 2, we investigate the hypothesis that the law of one price holds more nearly within regional groupings. Here we simply regress the measure of volatility of 
relative prices against regional dummy variables. ${ }^{b}$ For example, when the dependent variable is the standard deviation of $\mathrm{q}_{\mathrm{jk}}^{1}$, the North American dummy variable takes on a value of 1 if both locations $\mathrm{j}$ and $\mathrm{k}$ are within North America, and a zero otherwise. In the first column of Table 2, we report the result of regressing the standard deviation of the relative aggregate CPIs between locations (adjusted for the exchange rate) on dummy variables for North America, Europe and Asia. We find that the volatility is significantly lower for location pairs that are within North America or within Europe compared to the typical location pair. That conclusion is indicated by the significantly negative coefficients on the North American and European regional dummies. We note that the coefficient on the Asian dummy variable, however, is positive, though not significantly different from zero. It seems as though the law of one price holds no better between two Asian countries than between a typical pair of countries that are not within a regional grouping. But, because our Asian grouping consists of only four countries, we need to be very cautious in our interpretation.

Table 2, in fact, shows that across almost all of our individual goods, the law of one price holds more nearly for locations that are within North America or within Europe. The only case in which the coefficient on the North American or European dummies is not significantly less than zero is for the recreation goods category for Europe. The last column of Table 2 pools all of our goods together (not including the aggregate CPI) and constrains the coefficients on the dummy variables to be the same for all goods. We find the coefficient on the North American and European dummy variables are strongly significantly negative, while the Asian dummy variable has a coefficient that, while negative, is not significantly different from zero.

While Table 2 shows that the law of one price holds better among locations that are within North America or Europe, because the standard deviation of relative prices is

6 We include a dummy variable for each individual location, as well, 
lower for location pairs within those regions, it offers no clue as to why this might be true. We hypothesize three explanations for this finding: that nominal exchange rate variability is lower for these intra-regional pairs; that they are closer in distance to each other; and that their mutual trade barriers are lower.

So, we specify that the volatility ofq ${ }_{j \mathrm{k}}^{\mathrm{i}}$ is related to the natural $\log$ of the distance between locations $\mathrm{j}$ and $\mathrm{k}$. We choose the natural log function because it has been used in the empirical literature on distance and the volume of trade, and because it has the appealing property of being very concave. A priori, we doubt very much that if two countries are 7000 miles apart that adding another 500 miles makes much difference in their degree of integration, but there is a substantial difference between two countries that are 200 miles apart and two that are 700 miles apart.

Next, if nominal prices exhibit a particular kind of stickiness, then volatility of $q_{j k}^{i}$ should be closely related to variability of the nominal exchange rate between location $\mathrm{j}$ and $\mathrm{k}$. Specifically, if goods prices are set in the currency where the good is sold, the $q_{j k}^{i}$ should fluctuate one for one with the exchange rate.

One problem with including the volatility of the nominal exchange rate as a righthand-side variable intheregression is that it may beendogenous. That is, there maybe a relation between the volatility of the exchange rate and the volatility of $q_{j k}^{i}$ that is not causal. Exogenous shocks may influence both the exchange rate and $q_{j k}^{i}$. One way of dealing with this potential problem is by using instrumental variables. However, it is difficult to conceive of a valid instrument in this case. We estimate our basic equation using ordinary least squares, but we will return to this problem later.

We also consider measures of trade barriers: average tariff rates and the fraction of industries affected by non-tariff barriers.

If our marketing and distribution costs story has any merit, then the law of one price should hold more nearly for intra-regional pairs even when distance, exchange rate 
volatility and trade barriers are taken into account. So, we include the regional dummy variables in some of our specifications along with the other explanatory variables.

Finally, all of our regressions contain dummy variables for each location. That is, for the relative price $\mathrm{q}_{\mathrm{jk}}^{1}$, both the dummy variables for location $\mathrm{j}$ and location $\mathrm{k}$ receive a value of one. These variables are included as a way of dealing with different measurement practices in our various countries. Some countries may record prices in such a way as to increase (or decrease) their volatility compared to other countries. This will be reflected in a larger (smaller) than average coefficient on that country's dummy. Because we include a dummy for each location, there is no need to include a constant term in the regressions.

Table 3 reports regressions that include the log distance and the standard deviation of the nominal exchange rate as explanatory variables. Both variables do well in accounting for relative price variability. The coefficient on the distance variable has the correct sign for seven of the nine goods, and is significant in all of these cases. Only for health and transport does distance take on the wrong sign, but it is not statistically significant in either case.

The standard deviation of the nominal exchange rate is significant (and has the correct sign) in all of the regressions. In fact, this variable has exceptionally great power in explaining the standard deviation of relative prices. The t-statistics are all very large, even when the sample size is small. Moreover, the coefficients are large -ranging from .53 to 1.06. An increase in the standard deviation of nominal exchange rates of one unit translates into nearly a one unit increase in the standard deviation of relative prices. That is the type of response one would expect if nominal price stickiness were important. If nominal prices were completely fixed in the country where the good is sold, then nominal exchange rate variability would translate one for one into relative price variability. We do not see a one-to-one relation in our data, but it is 
close.

The final column of Table 3 reports regression results when the data for the eight goods (but not the aggregate CPI) are pooled. There we see that the effect of distance on price variability is positive and significant at the 5 per cent level. The border dummy variable receives a coefficient of .72 and is highly significant.

In the first line of Table 4, we include dummy variables for whether location pairs lie in North America, Europe or Asia. We note that these dummy variables are highly collinear with distance. We saw in Table 1 that location pairs within these regions tend to be much closer together than non-regional pairs. As a result of this collinearity, the individual significance of the distance coefficients and the regional dummies is diminished. But, across the regressions, patterns emerge which are worth noting.

First, nominal exchange rate variability is still significant and important quantitatively in these regressions.

Second, distance still is positive in seven of the nine regressions, but it is significant in only four.

Finally, the following patterns emerge for the regional dummies: the North American dummies and European dummies tend to be negative. For several of the individual goods regressions, these dummy variables have negative coefficients and are significant. For the regression using the aggregate CPI, both coefficients are negative and significant. Fortheregression that pools theindividual goods data, the North American dummy is negative and significant at the 5 per cent level, and the European dummy is negative and significant at the IO percent level (ina one-sided test). This indicates that price dispersion is lower among locations within these regions than average.

The results for the Asian dummy are more mixed. Most of the coefficients tend to be positive but insignificant. The coefficient in the regression using the pooled data, however, is negative and significant at the 10 per cent level. We note that the weak 
findings for the Asia region parallel the findings of Frankel, Stein and Wei (1995) who found weaker evidence that the Asian nations have formed a trading bloc than for North America or Europe.

In the second line of Table 3, we drop the distance variable, so that we use only the regional dummy variables and nominal exchange rate variability as explanatory variables, The statistical significance of the North American and European dummy variables jumps up for many of the individual goods. This is a result of the high collinearity between the regional dummy variables and distance. The Asian regional dummy variable is still insignificant in almost all of the regressions.

We tried various other dummy variables for regional groupings of location pairs: just the cities in Canada and the U. S.; the countries of the European Community, and the countries of the European Free Trade Association. These dummy variables generally are not significant.

We next ask whether formal trade barriers contribute to price dispersion. In Table 5 , we add two measures of trade barriers between pairs of countries to our regression that includes the log of distance and the standard deviation of the nominal exchange rate. The first measure is based on the trade-weighted average tariff rate in 1988. The tariff measure between location $\mathrm{j}$ and location $\mathrm{k}$ is taken to be $\left(1+\tau_{\mathrm{j}}\right)\left(1+\tau_{\mathrm{k}}\right)$, where $\tau_{\mathrm{i}}$ is the average tariff rate in location $\mathrm{i}(\mathrm{i}=\mathrm{j}, \mathrm{k})$. We adopt this measure since, following the discussion in Section 1 above, it gives a rough measure of the range of fluctuation in relative prices allowed for by constant tariff rates. When locations $\mathrm{j}$ and $\mathrm{k}$ are both cities within either Canada or the U. S., or if both are in Europe, we set the tariff measure equal to one. This measure of trade barriers is clearly very crude. It cannot distinguish any sort of discriminatory tariffs between two locations, except for the U.S. and Canadian cities and the European countries. Additionally, the barriers are only measured during one year, and are not distinguished by good. 
The second measure is based on a calculation of the fraction of traded goods industries affected by non-tariff barriers on imports for each country in 1988. To get the relevant observation for location $\mathbf{j k}$, we add the non-tariff barrier index for locations $\mathrm{j}$ and $\mathrm{k}$. For pairs of cities within the U.S. or Canada, and country pairs within Europe, this measure is set to zero.

There is a great deal of collinearity in the two measures of trade barriers, so we run regressions separately for the tariff measure and the non-tariff barrier measure. There is also high collinearity between the degree of openness and the regional dummies. We note that when all of these variables are included in the regression, essentially no individual coefficient is statistically significant.

In the first line of Table 5, we report results for regressions which include tariffs, distance and the standard deviation of the nominal exchange rate. We expect the coefficient on the tariff variable to be positive -- when there are higher tariff barriers there should be more relative price volatility. However, there is only one instance where the coefficient is positive and significant coefficients in these regressions -- in the regression for clothing.

The regression with non-tariff barriers included, along with distance and exchange rate volatility, is reported in the second line of Table 5. These results are puzzling. Generally we find that pairs of countries that have high non-tariff barriers actually have lower relative price dispersion. The coefficient on the non-tariff barriers is negative and significant in most regressions,

In general, however, we should probably not put too much stock in the regressions in Table 5, since our measures of trade barriers are so crude. In addition, the measures of trade barriers are highly correlated with the other explanatory variables. Table 6 displays the correlation matrix for our five right-hand-side variables: the log of distance, the standard deviation of the nominal exchange rate, tariffs, non-tariff 
barriers, and regional dummies. The regional dummy variable in this table has the form that location pair $\mathrm{jk}$ receives a value of one if both locations are within a single one of the three regions (North America, Europe, Asia), and a zero otherwise. The degree of correlation among these variables is striking. Location pairs that are within regions tend to be close together, have a stable exchange rate and have low trade barriers. So, it is difficult to separate out these effects on the law of one price.

Finally, in Table 7, we return to the issue of endogeneity of the nominal exchange rate. We have seen that in all of our regressions, the standard deviation of the exchange rate is highly significant. Our preferred explanation for this is that as $\mathbf{s}_{\mathbf{j k}}$, the nominal exchange rate between locations $j$ and $k$, varies, then $q_{j k}^{1}$ varies because of nominal price stickiness. We calculate $q_{j k}^{i}$ as $p_{j}^{i} / s_{j k} p_{k}^{i}$, where $p_{j}^{i}$ is the nominal price level in location $j$, expressed invocation $j$ 's currency, and similarly for $p_{k}^{i}$. If $p_{j}^{i}$ and $p_{k}^{i}$ are fixed (the most extreme form of nominal price stickiness) then $q_{j k}^{i}$ moves one for with $\mathrm{s}_{\mathbf{j k}}$.

However, an alternative explanation for the correlation of $s_{j k}$ and $q_{j k}^{i}$ is that both variables are influenced by some sort of real shocks. For example, shocks to productivity in the non-traded sectors in countries $j$ and $k$ might cause $q_{j k}^{i}$ to change. Monetary policy might be conducted in such a way that the nominal exchange rate tends to be influenced by the same real shocks,

If this type of explanation were true, the real shocks should also be reflected in $\mathrm{p}_{\mathrm{j}}^{1 / p_{j}}$ and $\mathrm{p}_{\mathrm{k}}^{1 / \mathrm{p}_{\mathrm{k}}}$, where $\mathrm{p}_{\mathrm{j}}$ and $\mathrm{p}_{\mathrm{k}}$ represent the aggregate CPIS in locations $\mathrm{j}$ and $\mathrm{k}$. That is, real shocks that affect relative prices will cause the price of good i to vary relative to the overall price level in each location. So, we consider an alternate measure of the relative price variability between locations $\mathrm{j}$ and $\mathrm{k}: \widetilde{\mathbf{q}}_{\mathbf{j k}}^{\mathrm{i}} \equiv$ $\left(p_{j}^{i} / p_{j}\right) /\left(p_{k}^{i} / p_{k}\right)$.

Summary statistics for these "relative relative" prices are presented in the bottom 
half of Table 1. There we report the average standard deviation of $\tilde{\mathrm{q}}_{\mathbf{j k}}^{1}$ for location pairs in various regions.

In Table 7, we regress the standard deviation of $\widetilde{q}_{j \mathbf{k}}^{\mathrm{i}}$ on log of distance and the standard deviation of the nominal exchange rate. With the exception of the regression for food (and the pooled regression), the coefficients on the nominal exchange rate variable are still positive and significant in all of the regressions. This correlation cannot be a result of fluctuating nominal exchange rates and sticky nominal prices, since the nominal exchange rate does not appear in the calculation of $\tilde{\mathbf{q}}_{\mathrm{jk}}^{\mathrm{i}}$. This indicates some simultaneity in the determination of nominal exchange rate variation and relative price variation. Both may be responding to real shocks.

Of course, the ideal way to deal with this problem statistically is to use an instrumental variable for the nominal exchange rate variable, but we were unable to find a satisfactory instrument. We note that in the regressions reported in Table 7, the explanatory power for nominal exchange rate variability is much lower than in our other regressions, while still statistically significant in most cases. This probably means that while the mutual response of relative prices and the nominal exchange rate to real shocks accounts for some of the correlation we find between the standard deviation of $q_{j k}^{i}$ and $\mathrm{s}_{\mathrm{jk}}$, it does not account for mOSt Of it. It is likely that nominal-price stickiness accounts for much of this relation,

\section{Conclusions}

Our empirical analysis indicates that nominal exchange rate variability and distance between locations accounts for much of the failure of the law of one price between locations. We also find some evidence that locations within regions have lower relative price variability even taking into account these factors.

Nominal price stickiness accounts for large divergences in prices between 
locations. Asthenominal exchange rate varies, relative prices swing widely. However, we also note that to some extent the nominal exchange rate and relative prices respond to common shocks. The significance of sticky prices for allocation of resources is an open question. It could be that these failures of the law of one price represent significant distortions. The relative price of a good should respond to its relative scarcity. But, when we look at prices of similar goods between locations, prices do not seem to be responding to those types of signals. It is not clear to what extent resources are misallocated as a result. It is possible that non-price mechanisms have developed that circumvent the problem. This is certainly an important area for future research.

When we include only distance along with nominal exchange rate variability in our regressions, we find that locations which are more distant are less integrated. This result is not surprising, and is consistent with the findings of the gravity model of trade. We note, however, that distance may matter for reasons other than simply transportation costs. Engel and Rogers (1995) find evidence that labor markets are more closely integrated for nearby locations. In that study, price dispersion was found to be significantly influenced by wage dispersion. This is interesting, because if distance matters for regionalization because of transportation costs, then there is little that policy-makers can hope to achieve to increase market integration. But, there may be some room for increased integration if factor markets can be made more open. We note, however, that the significance of distance as an explanatory variable drops when regional dummy variables are added to the regressions, although its significance does not entirely disappear.

Our crude measures of trade barriers finds little evidence to confirm the hypothesis that greater protection leads to greater price variability among regions. We hesitate to conclude from this that trade barriers have little effect on final goods prices, however. First, as we explain, our measures of trade barriers are aggregate 
measures undifferentiated by good, by country of origin of the import, or by time.

Second, there is a high degree of collinearity between our measure of openness and our other explanatory variables, so it is difficult to separate out their individual effects.

Finally, we find that relative price dispersion is affected by whether or not the location pair are within a region. For European and North American locations, relative price variability is significantly smaller than for other location pairs. We have offered a potential explanation for why regions matter: that distribution and marketing are more integrated for locations within regions. We can offer, however, no direct evidence on this hypothesis. We note that price dispersion is not reduced for country pairs within the Asian region.

The question of whether markets have become more regionalized is an interesting one. It is sparked by the observation that regional trade arrangements have increased in number and perhaps importance in recent years. But, our findings suggest that further study of regionalization can be greatly enhanced by taking a broader view of the determinants of market integration. 
Our data set contains monthly consumer prices from January 1980 to December 1994. The data is taken form Datastream, and consists of eight disaggregated components of the CPI: food; fuel and electricity; housing; clothing; health; transportation; recreation and education; and, household equipment, durables and furniture. We also use data on the overall CPI.

In addition, comparable CPI data for four Canadian cities -- Ottawa, Toronto, Winnipeg and Vancouver -- was obtained from Statistics Canada. Data for four U.S. cities -- New York, Los Angeles, Chicago, and Philadelphia -- is from the Bureau of Labor Statistics.

All of the price data is seasonally unadjusted.

Nominal exchange rates are monthly averages from the IMF's International Financial Statistics.

Distances are calculated as great circle distances between locations, obtained from PCGLOBE. They are measured from a country's capital when country data is used.

The data on average tariff rates and non-tariff barriers is from Lee and Swagel, who in turn obtained the data from the UNCTAD Micro TCM System. The tariff data is the trade-weighted average tariff rate. The non-tariff barrier numbers are the fraction of Customs Cooperation Council Nomenclature four or 5 digit categories in each country for which any non-tariff barriers are in place. Both series were measured in 1988. 


\section{Appendix 2}

We prove the two propositions at the end of section 2.A.

First, take the case of $\phi=\phi^{*}$. Suppose that $1 / \eta^{*}<1 / \gamma$, so that

$$
\mathrm{P} 2=\mathrm{p}_{2}^{*}<\mathrm{p}^{*}=\mathrm{p}_{1}^{*} \text {. }
$$

Now, note that

$$
\mathrm{p}^{(\phi-1) / \phi}=\omega \mathrm{p}_{1}^{(\phi-1) / \phi}+(1-\omega) \mathrm{p}_{2}^{(\phi-1) / \phi} \quad \mathrm{p}_{1}^{(\phi-1) / \phi}
$$

sop $<\mathrm{p}_{1}$. Likewise, $\mathrm{p}_{2}^{*}<\mathrm{p}^{*}$. If $\omega>\omega^{*}$, thenp" $<\mathrm{p}$. So,

$$
\mathrm{p}_{2}^{*}<\mathrm{p}^{*}<\mathrm{p}<\mathrm{p},
$$

Thus, we have $1<\mathrm{p} / \mathrm{p}^{*}<\mathrm{p}_{1} / \mathrm{p}_{2}^{*}$. Analogously, if $1 / \gamma<1 / \mathrm{n}^{*}$, we have $\mathrm{p}_{1} / \mathrm{p}_{2}^{*}<\mathrm{p} / \mathrm{p}^{*}<1$. So, $\mathrm{p} / \mathrm{p}^{*}$ is closer to unity than $\mathrm{p}_{1} / \mathrm{p}_{2}^{*}$.

If $\phi \neq \phi^{*}, \mathrm{p} / \mathrm{p}^{*}$ may be farther from unity than $\mathrm{p}_{1} / \mathrm{p}_{2}^{*}$. Suppose, for example that $1 / q^{*}<1 / \gamma$. Then, from above, $p<p_{1}$ and $p_{2}^{*} C p^{*}$. It is possible, if the mark-ups are sufficiently different, that $p_{1}<p_{2}^{*}$, even with $1 / n^{*}<1 / \gamma$. In that case, we have

$$
\mathrm{p}<\mathrm{p},<\mathrm{p}_{2}^{*}<\mathrm{p}^{*}
$$

so, $1<\mathrm{p}_{1} / \mathrm{p}_{2}^{*}<\mathrm{p} / \mathrm{p}^{*}$. In this case, $\mathrm{p} / \mathrm{p}^{*}$ is farther from unity than $\mathrm{p}_{1} / \mathrm{p}_{2}^{*}$. 


\section{$\underline{\text { References }}$}

Cumby, Robert, 1993, Forecasting exchange rates on the hamburger standard: What you see is what you get with McParity," manuscript, Georgetown University.

Dombusch, Rudiger, 1987, Exchange rates and prices, American Economic Review 77, 93-106.

Engel, Charles, 1993, Real exchange rates and relative prices: An empirical investigation, Journal of Monetary Economics 32, 35-50.

Engel, Charles and John H. Rogers, 1995, How wide is the border?, manuscript, University of Washington.

Frankel, Jeffrey; Emesto Stein, and Shang-Jin Wei, 1994, Trading blocs and the Americas: The natural, the unnatural and the super-natural, Journal of Development Economics 47, 61-96.

Froot, Kenneth A. and Paul D. Klemperer, 1989, Exchange rate pass-through when market share matters, American Economic Review 79, 637-654.

Froot, Kenneth A.; Michael Kim; and Kenneth Rogoff, 1995, The law of one price over 700 years, National Bureau of Economic Research working paper no. 5132.

Ghosh, Atish R. and Holger C. Wolf, 1994, Pricing in international markets: Lessons from the Economist, National Bureau of Economic Research working paper no. 4806.

Isard, Peter, 1977, How far can we push the law of one price?, American Economic Review 67, 942-948.

Knetter, Michael N., 1989, Price discrimination by U.S. and German exporters, American Economic Review 79, 198-210.

Knetter, Michael N., 1994, Why are retail prices in Japan so high?: Evidence from German export prices, National Bureau of Economic Research working paper no. 4894.

Krugman, Paul, 1987, Pricing to market when the exchange rate changes, in Sven W. Arndt and J. David Richardson, eds., Real-Financial Linkages among Open Economies (Cambridge: M.I.T. Press).

Lee, Jong-Wha and Phillip Swagel, 1994, Trade barriers and trade flows across countries and industries, Board of Governors of the Federal Reserve System, International Finance Discussion Papers no. 476.

Mankiw, N. Gregory, 1985, Small menu costs and large business cycles: A macroeconomic model of monopoly, Quarterly Journal of Economics 100, 529-539.

Mussa, Michael, 1986, Nominal exchange rate regimes and the behavior of real exchange rates: Evidence and implications, in K. Brunner and A. Meltzer, eds., CarnegieRochester Conference Series on Public Policy 25, 117-214. 
Rogers, John H. and Michael Jenkins, 1994, Haircuts or hysteresis? Sources of movements in real exchange rates, Journal of International Economics 38, 339-360.

Sanyal, Kalyan and Ronald Jones, 1982, The theory of trade in middle products, American Economic Review 72, 16-31.

Wei, Shang-Jin and David C. Parsley, 1995, Purchasing power disparity during the floating rate period: Exchange rate volatility, trade barriers and other culprits, National Bureau of Economic Research working paper no. 5032. 
Table 1: Selected Summary Statistics

Std. Dev (\%) /

Regional Pairs: N. America U.S.-Can. Europe $\mathrm{EC}$ Asia

\begin{tabular}{|l|c|c|c|c|c|}
\hline Aggregate CPI & 2.05 & 1.80 & 1.40 & 1.75 & 2.33 \\
\hline Nominal exch. rate & 1.72 & 0.55 & 1.23 & 1.51 & 2.01 \\
\hline \hline Food & 2.20 & 1.02 & 1.66 & 2.14 & 2.92 \\
\hline Housing & 2.41 & 1.22 & 1.56 & 2.19 & 2.21 \\
\hline Fuel \& Electricity & 2.91 & 2.91 & 2.41 & 2.63 & N/A \\
\hline Clothing & 2.97 & 2.55 & 3.63 & 1.85 & 3.35 \\
\hline Transportation & 2.25 & 1.85 & 4.83 & 10.3 & 2.82 \\
\hline H.H. Equipment & 3.09 & 1.34 & 2.03 & 2.42 & 2.86 \\
\hline Health & 2.85 & 1.15 & 1.80 & N/A & 3.12 \\
\hline Recreation & 1.21 & 1.21 & 1.99 & N/A & 3.39 \\
\hline \hline Food / CPI & 0.82 & 0.76 & 0.87 & .1 .14 & 1.37 \\
\hline Housing / CPI & 1.04 & 0.85 & 1.08 & 1.55 & 1.08 \\
\hline Fuel \& Electr. / CPI & 2.69 & 2.69 & 1.84 & 2.08 & N/A \\
\hline Clothing / CPI & 2.01 & 2.40 & 3.11 & 1.56 & 2.76 \\
\hline Transportation / CPI & 1.73 & 1.68 & 1.97 & 3.19 & 1.22 \\
\hline H.H. Equipment/ CPI & 1.61 & $\mathbf{1 . 1 4}$ & 0.94 & 1.20 & 0.40 \\
\hline Health / CPI & 1.46 & 1.04 & 1.15 & N/A & 1.19 \\
\hline Recreation / CPI & 1.08 & 1.08 & 1.08 & N/A & 1.58 \\
\hline \hline $\begin{array}{l}\text { Avg. Distance } \\
\text { Between Locations }\end{array}$ & $1,389 \mathrm{mi}$. & $1,210 \mathrm{mi}$. & $651 \mathrm{mi}$. & $733 \mathrm{mi}$. & $1,738 \mathrm{mi}$. \\
\hline
\end{tabular}

Notes: Column entries give the standard deviation of the relative price (the average standard deviation across all combinations) within the stated region. Each of the relative prices used is in terms of $\log$ first-differences. The average distance between locations is given in the final row. N/A indicates that there are no more than 1 pair of locations in the grouping.

The following locations are included (by region):

North America: Chicago, Los Angeles, New York, and Philadelphia, Ottawa, Toronto, Vancouver, Winnipeg, and Mexico;

Asia: Hong Kong, Japan, Singapore, and Taiwan;

Europe: Austria, Belgium, Denmark, Finland, France, Germany, Greece, Italy, Netherlands, Norway, Portugal, Spain, Sweden, Swizzerland, and United Kingdom.

EC: Belgium, Denmark, France, Germany, Greece, Italy, Netherlands,Portugal, Spain, U.K. 
Table 2: Regressions Relating Price Volatility to Regional Dummies

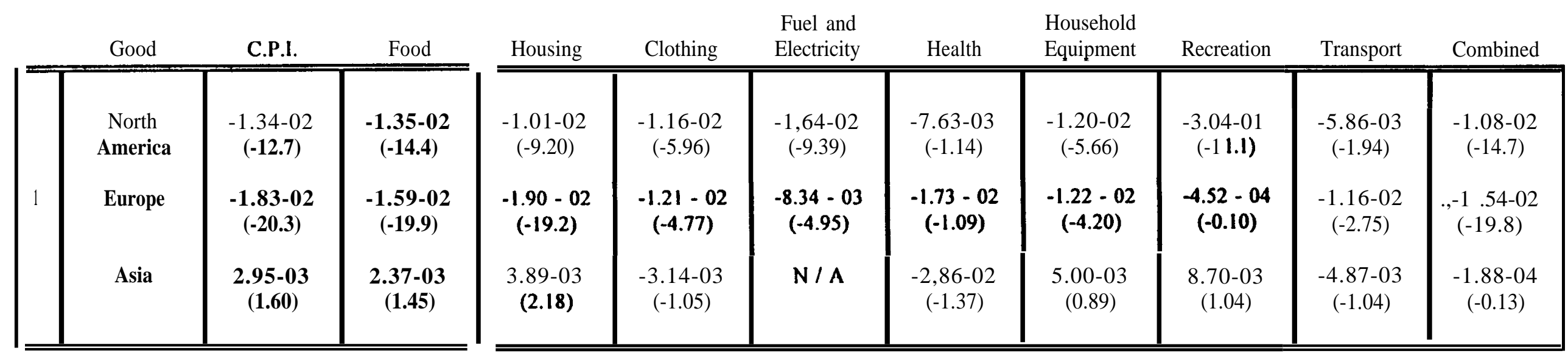

Notes: All regressions contain as explanatory variables a dummy for each individual location, in addition to the variables listed in the cell. Individual goods dummies are contained in the combined regression. Heteroscedastici -consistent t-statistics [White (1980)] are reported in parenthesis. The dependent variable is the standard deviation of the first-difference in the relative price. Japan is the only one of the Asian countries for which data on fuel and electricity is available. 
Table 3: Relative Price Volatility, Distance, and Nominal Exchange Rate Volatility

\begin{tabular}{|c|c|c|c|c|c|c|c|c|c|c|c|}
\hline & Good & C.P.I. & Food & Housing & Clothing & $\begin{array}{c}\text { Fuel and } \\
\text { Electricity }\end{array}$ & Health & $\begin{array}{l}\text { Household } \\
\text { Equipment }\end{array}$ & Recreation & Transport & Combined \\
\hline \multirow{3}{*}{1} & $\begin{array}{c}\log \\
\text { (Distance) }\end{array}$ & $\begin{array}{c}9.55-04 \\
(3.71)\end{array}$ & $\begin{array}{c}1.25-03 \\
(5.41)\end{array}$ & $\begin{array}{c}6.39-04 \\
(2.24)\end{array}$ & $\begin{array}{c}2.23-03 \\
(3.29)\end{array}$ & $\begin{array}{c}9.49-04 \\
(2.46)\end{array}$ & $\begin{array}{c}-4.45-04 \\
(-1.52)\end{array}$ & $\begin{array}{c}1.13-03 \\
(1.53)\end{array}$ & $\begin{array}{c}8.57-04 \\
(5.72)\end{array}$ & $\begin{array}{c}-8.77-04 \\
(-1.26)\end{array}$ & $\begin{array}{c}7.89-04 \\
(3.15)\end{array}$ \\
\hline & $\begin{array}{l}\mathrm{SD} \text { (Nom. } \\
\text { Exch. Rate) }\end{array}$ & $\begin{array}{c}0.85 \\
(31.6)\end{array}$ & $\begin{array}{c}0.74 \\
(30.7)\end{array}$ & $\begin{array}{c}0.77 \\
(26.0)\end{array}$ & $\begin{array}{c}0.53 \\
(6.12)\end{array}$ & $\begin{array}{c}0.57 \\
(15.0)\end{array}$ & $\begin{array}{c}1.06 \\
(27.5)\end{array}$ & $\begin{array}{c}0.66 \\
(7.41)\end{array}$ & $\begin{array}{c}0.76 \\
(25.4)\end{array}$ & $\begin{array}{c}1.02 \\
\text { (12.1) }\end{array}$ & $\begin{array}{c}0.72 \\
(26.3)\end{array}$ \\
\hline & $\begin{array}{l}\text { \# of pairs } \\
\text { in sample }\end{array}$ & 406 & 406 & 325 & 171 & 190 & 91 & 120 & 91 & 153 & 1547 \\
\hline
\end{tabular}

Notes: The regression contains a dummy for each individual location, in addition to the variables listed in the cell. Individual goods dummies are contained in the combined regression. Heteroscedasticity-consistent t-statistics [White (1980)] are reported in parenthesis. The dependent variable is the standard deviation of the first-difference in the relative price.

For each good, the sample includes the following locations:

C.P.I. and Food - all countries in Table 1 plus South Africa; Housing - all North America and Asia, all Europe except Portugal and Sweden; Clothing - all North America and Asia, plus Italy, Netherlands, Norway, Sweden, U.K. and South Africa; Fuel and Electricity - all North America except Mexico, plus Japan, and all Europe except Greece, Portugal, Spain and Sweden; Household Equipment - all North America, Japan, Hong Kong, Denmark, Norway, Sweden, U. K., and South Africa; Transportation - all North America and Asia, Denmark, Netherlands, Norway, Sweden, and Switzerland; Health - all North America, Japan, Taiwan, Netherlands, Norway, and Switzerland; Recreation - all North America except Mexico, plus Japan, Taiwan, Norway, Sweden, and Switzerland. 
Table 4: Regressions Relating Price Volatility to Nominal Exchange Rate Volatility, Distance and Regional Dummies

\begin{tabular}{|c|c|c|c|c|c|c|c|c|c|c|c|}
\hline & Good & C.P.I. & Food & Housing & Clothing & $\begin{array}{c}\text { Fuel and } \\
\text { Electricity }\end{array}$ & Health & $\begin{array}{l}\text { Household } \\
\text { Equipment }\end{array}$ & Recreation & Transport & Combined \\
\hline & $\begin{array}{c}\log \\
\text { (Distance) }\end{array}$ & $\begin{array}{c}3.33-04 \\
(0.94)\end{array}$ & $\begin{array}{c}6.81-04 \\
(2.18)\end{array}$ & $\begin{array}{c}-7.57-05 \\
(-0.18)\end{array}$ & $\begin{array}{c}2.68-04 \\
(0.23)\end{array}$ & $\begin{array}{c}1.51-03 \\
(3.33)\end{array}$ & $\begin{array}{c}4.06-04 \\
(0.98)\end{array}$ & $\begin{array}{c}7.30-05 \\
(0.07)\end{array}$ & $\begin{array}{c}9.24-04 \\
(5.80)\end{array}$ & $\begin{array}{c}-2.53-04 \\
(-0.23)\end{array}$ & $\begin{array}{c}-1.73-04 \\
(-0.47)\end{array}$ \\
\hline & $\begin{array}{l}\text { SD (Nom. } \\
\text { Exch. Rate) }\end{array}$ & $\begin{array}{c}0.78 \\
(22.4)\end{array}$ & $\begin{array}{c}0.68 \\
(22.2)\end{array}$ & $\begin{array}{c}0.68 \\
\mathbf{( 1 7 . 2 )}\end{array}$ & $\begin{array}{c}0.47 \\
(4.19)\end{array}$ & $\begin{array}{c}0.67 \\
(11.9)\end{array}$ & $\begin{array}{c}1.00 \\
(24.7)\end{array}$ & $\begin{array}{c}0.57 \\
(5.43)\end{array}$ & $\begin{array}{c}0.76 \\
(19.1)\end{array}$ & $\begin{array}{c}1.05 \\
(12.0)\end{array}$ & $\begin{array}{c}0.68 \\
(20.0)\end{array}$ \\
\hline & $\begin{array}{c}\text { North } \\
\text { America }\end{array}$ & $\begin{array}{c}-3.55-03 \\
(-3.84)\end{array}$ & $\begin{array}{c}-4.21-03 \\
(-5.17)\end{array}$ & $\begin{array}{c}-3.18-03 \\
(-3.06)\end{array}$ & $\begin{array}{c}-5.92-03 \\
(-2.02)\end{array}$ & $\begin{array}{c}3.97-03 \\
(2.03)\end{array}$ & $\begin{array}{c}6.70-03 \\
(2.87)\end{array}$ & $\begin{array}{c}-3.61-03 \\
(-1.24)\end{array}$ & $\begin{array}{c}7.32-04 \\
(0.63)\end{array}$ & $\begin{array}{c}1.76-03 \\
(0.65)\end{array}$ & $\begin{array}{c}-3.73-03 \\
(-4.07)\end{array}$ \\
\hline & Europe & $\begin{array}{c}-2.42-03 \\
(-2.52)\end{array}$ & $\begin{array}{c}-1.39-03 \\
(-1.64)\end{array}$ & $\begin{array}{c}-3.46-03 \\
(-2.82)\end{array}$ & $\begin{array}{c}-3.65-03 \\
(-1.03)\end{array}$ & $\begin{array}{c}2.68-03 \\
(1.71)\end{array}$ & $\begin{array}{c}-8.13-03 \\
(-2.21)\end{array}$ & $\begin{array}{c}-4.61-03 \\
(-1.32)\end{array}$ & $\begin{array}{c}-9.61-04 \\
(-0.90)\end{array}$ & $\begin{array}{c}3.50-03 \\
(0.88)\end{array}$ & $\begin{array}{c}-1.76-03 \\
(-1.55)\end{array}$ \\
\hline & Asia & $\begin{array}{c}8.84-04 \\
(0.65)\end{array}$ & $\begin{array}{c}1.29-03 \\
(1.07)\end{array}$ & $\begin{array}{c}6.19-04 \\
(0.41)\end{array}$ & $\begin{array}{c}-4.51-03 \\
(-1.27)\end{array}$ & $\mathrm{N} / \mathrm{A}^{\prime}$ & $\begin{array}{c}-5.31-03 \\
(-1.10)\end{array}$ & $\begin{array}{c}1.20-02 \\
(0.23)\end{array}$ & $\begin{array}{c}2.29-03 \\
(1.04)\end{array}$ & $\begin{array}{c}-1.48-03 \\
(-0.41)\end{array}$ & $\begin{array}{c}-2.15-03 \\
(-1.55)\end{array}$ \\
\hline & $\begin{array}{l}\text { SD (Nom. } \\
\text { Exch. Rate) }\end{array}$ & $\begin{array}{c}0.78 \\
(23.4)\end{array}$ & $\begin{array}{c}0.69 \\
(23.4)\end{array}$ & $\begin{array}{c}0.68 \\
(17.7)\end{array}$ & $\begin{array}{c}0.47 \\
(4.23)\end{array}$ & $\begin{array}{c}0.71 \\
(12.5)\end{array}$ & $\begin{array}{c}1.03 \\
(36.5)\end{array}$ & $\begin{array}{c}0.57 \\
(5.50)\end{array}$ & $\begin{array}{c}0,93 \\
(27.7)\end{array}$ & $\begin{array}{c}1.04 \\
(12.3)\end{array}$ & $\begin{array}{c}0.68 \\
(20.1)\end{array}$ \\
\hline 2 & $\begin{array}{l}\text { North } \\
\text { America }\end{array}$ & $\begin{array}{c}-4.00-03 \\
(-5.11)\end{array}$ & $\begin{array}{c}-5.15-03 \\
(-7.40)\end{array}$ & $\begin{array}{c}-3.07-03 \\
(-3.58)\end{array}$ & $\begin{array}{c}-6.36-03 \\
(-2.87)\end{array}$ & $\begin{array}{c}2.65-03 \\
(1.34)\end{array}$ & $\begin{array}{c}5.01-03 \\
(3.19)\end{array}$ & $\begin{array}{c}-3.72-03 \\
(-1.56)\end{array}$ & $\begin{array}{c}1.01-03 \\
(0,72)\end{array}$ & $\begin{array}{l}2.14-03 \\
(0.99)\end{array}$ & $\begin{array}{c}-3,48-03 \\
(-4.64)\end{array}$ \\
\hline & Europe & $\begin{array}{c}-2.78-03 \\
(-3.16)\end{array}$ & $\begin{array}{c}-2.13-03 \\
(-2.73)\end{array}$ & $\begin{array}{c}-3.37-03 \\
(-3.01)\end{array}$ & $\begin{array}{c}-4.06-03 \\
(-1.32)\end{array}$ & $\begin{array}{c}-6.20-06 \\
(-0.004)\end{array}$ & $\begin{array}{c}-7.56-03 \\
(-2,09)\end{array}$ & $\begin{array}{c}-4.74-03 \\
(-1.64)\end{array}$ & $\begin{array}{c}-4.06-04 \\
(-0.32)\end{array}$ & $\begin{array}{c}4.06-03 \\
(1.28)\end{array}$ & $\begin{array}{c}-1.48-03 \\
(-1.52)\end{array}$ \\
\hline & Asia & $\begin{array}{c}2.42-04 \\
(0.20)\end{array}$ & $\begin{array}{c}-2.73-05 \\
(-0.03)\end{array}$ & $\begin{array}{c}7.68-04 \\
(0.61)\end{array}$ & $\begin{array}{c}-5.00-03 \\
(-1.74)\end{array}$ & $N / A^{*}$ & $\begin{array}{c}-5.45-03 \\
(-1.13)\end{array}$ & $\begin{array}{c}1.09-03 \\
(0.22)\end{array}$ & $\begin{array}{c}-1,77-03 \\
(-0.70)\end{array}$ & $\begin{array}{c}-1.11-03 \\
(-0.35)\end{array}$ & $\begin{array}{c}-1.86-03 \\
(-1.49)\end{array}$ \\
\hline
\end{tabular}

Notes: All regressions contain as explanatory variables a dummy for each individual location, in addition to the variables listed in the cell. Individual goods dummies are contained in the combined regression. Heteroscedasticity-consistent t-statistics [White (1980)] are reported in parenthesis. The dependent variable is the standard deviation of the first-difference in the relative price. (a) Japan is the only one of the Asian countries for which data is available for this good. 
Table 5: Regressions Relating Price Volatility to Distance and Trade Barriers

\begin{tabular}{|c|c|c|c|c|c|c|c|c|c|c|c|}
\hline & Good & C.P.I. & Food & Housing & Clothing & $\begin{array}{l}\text { Fuel and } \\
\text { Electricity }\end{array}$ & Health & $\begin{array}{l}\text { Household } \\
\text { Equipment }\end{array}$ & Recreation & Transport & Combined \\
\hline \multirow{3}{*}{ I } & $\begin{array}{c}\log \\
\text { (Distance) }\end{array}$ & $\begin{array}{c}1.03-03 \\
(3.74)\end{array}$ & $\begin{array}{c}1.31-03 \\
(5.33)\end{array}$ & $\begin{array}{c}7.24-04 \\
(2.46)\end{array}$ & $\begin{array}{c}2.12-03 \\
(3.13)\end{array}$ & $\begin{array}{c}9.17-04 \\
(2.38)\end{array}$ & $\begin{array}{c}1.56-04 \\
(0.24)\end{array}$ & $\begin{array}{c}1.15-03 \\
(1.45)\end{array}$ & $\begin{array}{c}7.81-04 \\
(2.70)\end{array}$ & $\begin{array}{c}-8.65-04 \\
(-1.20)\end{array}$ & $\begin{array}{c}8.26-04 \\
(3.26)\end{array}$ \\
\hline & $\begin{array}{l}\text { SD (Nom. } \\
\text { Exch. Rate) }\end{array}$ & $\begin{array}{c}0.89 \\
(22.9)\end{array}$ & $\begin{array}{c}0,78 \\
(22.4)\end{array}$ & $\begin{array}{c}0.81 \\
(19.5)\end{array}$ & $\begin{array}{c}0.35 \\
(2.74)\end{array}$ & $\begin{array}{c}0.53 \\
(10.5)\end{array}$ & $\begin{array}{c}1.07 \\
(26.4)\end{array}$ & $\begin{array}{c}0.66 \\
(4.37)\end{array}$ & $\begin{array}{c}0.76 \\
(25.2)\end{array}$ & $\begin{array}{c}1.03 \\
(10.5)\end{array}$ & $\begin{array}{c}0.73 \\
(19.0)\end{array}$ \\
\hline & Tariff & $\begin{array}{c}-8.66-03 \\
(-1.34)\end{array}$ & $\begin{array}{c}-8.52-03 \\
(-1.47)\end{array}$ & $\begin{array}{c}-9.03-02 \\
(-1.24)\end{array}$ & $\begin{array}{c}3.62-02 \\
(1.96)\end{array}$ & $\begin{array}{c}9.14-03 \\
(1.21)\end{array}$ & $\begin{array}{c}-6.70-03 \\
(-1.03)\end{array}$ & $\begin{array}{c}-1.53-03 \\
(-0.08)\end{array}$ & $\begin{array}{c}7.17-04 \\
(0.31)\end{array}$ & $\begin{array}{c}-8.21-04 \\
(-0.07)\end{array}$ & $\begin{array}{c}-1.96-03 \\
(-0.32)\end{array}$ \\
\hline \multirow{3}{*}{2} & $\begin{array}{c}\text { Log } \\
\text { (Distance) }\end{array}$ & $\begin{array}{c}1.09-03 \\
(4.05)\end{array}$ & $\begin{array}{c}1.33-03 \\
(5.51)\end{array}$ & $\begin{array}{c}8.49-04 \\
(3.02)\end{array}$ & $\begin{array}{c}2.29-03 \\
(3.35)\end{array}$ & $\begin{array}{c}9.46-04 \\
(2.45)\end{array}$ & $\begin{array}{c}-3.22-04 \\
(-1.09)\end{array}$ & $\begin{array}{c}9.17-04 \\
(1.27)\end{array}$ & $\begin{array}{c}7.90-04 \\
(5.73)\end{array}$ & $\begin{array}{c}-6.81-04 \\
(-1.05)\end{array}$ & $\begin{array}{c}8.63-04 \\
(3.44)\end{array}$ \\
\hline & $\begin{array}{l}\text { SD (Nom. } \\
\text { Exch. Rate) }\end{array}$ & $\begin{array}{c}0.92 \\
(27.8)\end{array}$ & $\begin{array}{c}0.79 \\
(26,5)\end{array}$ & $\begin{array}{c}0.85 \\
(25.1)\end{array}$ & $\begin{array}{c}0.58 \\
(5.67)\end{array}$ & $\begin{array}{c}0.55 \\
(12,4)\end{array}$ & $\begin{array}{c}1.06 \\
(28.0)\end{array}$ & $\begin{array}{c}0.92 \\
(8.38)\end{array}$ & $\begin{array}{c}0.81 \\
(26.9)\end{array}$ & $\begin{array}{c}1.18 \\
(13.8)\end{array}$ & $\begin{array}{c}0.80 \\
(24.7)\end{array}$ \\
\hline & NTB & $\begin{array}{c}-5.88-05 \\
(-3.62)\end{array}$ & $\begin{array}{c}-4.12-05 \\
(-2.81)\end{array}$ & $\begin{array}{c}-7.62-05 \\
(-4.46)\end{array}$ & $\begin{array}{c}-3.34-05 \\
(-0.83)\end{array}$ & $\begin{array}{c}1.25-05 \\
(0.69)\end{array}$ & $\begin{array}{c}-4.99-05 \\
(-1.96)\end{array}$ & $\begin{array}{c}-1.53-04 \\
(-4.12)\end{array}$ & $\begin{array}{c}-4.47-05 \\
(-3.98)\end{array}$ & $\begin{array}{c}-1.99-04 \\
(-4.70)\end{array}$ & $\begin{array}{c}-6.76-05 \\
(-4.83)\end{array}$ \\
\hline
\end{tabular}

Notes: All regressions contain as explanatory variables a dummy for each individual location, in addition to the variables listed in the cell. Individual goods dummies are contained in the combined regression. Heteroscedasticity-consistent t-statistics [White (1980)] are reported in parenthesis. The dependent variable is the standard deviation of the first-difference in the relative price. The sample includes the locations listed in Table 2. 
Table 6: Correlation Matrix of Right-Hand Side Variables

\begin{tabular}{|l|c|c|c|c|c|}
\hline & Log (Distance) & $\begin{array}{c}\text { Std Dev. Nom. } \\
\text { Exch. Rate }\end{array}$ & Tariff & NTB & $\begin{array}{c}\text { Region } \\
\text { Dummy }\end{array}$ \\
\hline Log (Distance) & 1.00 & & & & \\
\hline SD Exch. Rate & 0.49 & 1.00 & & & \\
\hline Tariff & 0.67 & 0.58 & 1.00 & & \\
\hline NTB & 0.54 & 0.25 & 0.73 & 1.00 & \\
\hline Reg'n Dummy & -0.87 & -0.46 & -0.71 & -0.57 & 1.00 \\
\hline
\end{tabular}

Notes: Entries give the correlation between each pair of series. Region dummy is unity when each country in a pair is in the same region, and is zero otherwise. The other series are as defined in the text. 
Table 7: Relative-Relative Price Volatility, Distance, and Nominal Exchange Rate Volatility

\begin{tabular}{|c|c|c|c|c|c|c|c|c|c|c|}
\hline & Good & Food & Housing & Clothing & $\begin{array}{l}\text { Fuel and } \\
\text { Electricity }\end{array}$ & Health & $\begin{array}{l}\text { Household } \\
\text { Equipment }\end{array}$ & Recreation & Transport & Combined \\
\hline & $\begin{array}{c}\mathbf{L o g} \\
\text { (Distance) }\end{array}$ & $\begin{array}{c}3.89-04 \\
(5.54)\end{array}$ & $\begin{array}{c}-8.57-04 \\
(-0.77)\end{array}$ & $\begin{array}{c}1.28-03 \\
(2.29)\end{array}$ & $\begin{array}{c}2.45-04 \\
(0.61)\end{array}$ & $\begin{array}{c}1.87-04 \\
(1.21)\end{array}$ & $\begin{array}{c}2.83-05 \\
(0.23)\end{array}$ & $\begin{array}{c}6.19-04 \\
(4.02)\end{array}$ & $\begin{array}{c}-5.51-04 \\
(-2.10)\end{array}$ & $\begin{array}{c}1.76-05 \\
(0.07)\end{array}$ \\
\hline 1 & $\begin{array}{l}\text { SD (Nom. } \\
\text { Exch. Rate) }\end{array}$ & $\begin{array}{c}-9.85-03 \\
(-1.30)\end{array}$ & $\begin{array}{c}2.49-02 \\
(2.15)\end{array}$ & $\begin{array}{l}0.15 \\
(2.11)\end{array}$ & $\begin{array}{c}0.1 \mathrm{I} \\
(2.82)\end{array}$ & $\begin{array}{c}0.13 \\
(6.24)\end{array}$ & $\begin{array}{c}4.09-02 \\
(2.74)\end{array}$ & $\begin{array}{c}6.90-02 \\
(2.23)\end{array}$ & $\begin{array}{c}0.33 \\
(10.2)\end{array}$ & $\begin{array}{c}6.77-02 \\
(2.56)\end{array}$ \\
\hline
\end{tabular}

Notes: The regression contains a dummy for each individual location, in addition to the variables listed in the cell. Individual goods dummies arc contained in the combined regression. Heteroscedasticity-consistent t-statistics [White (1980)] are reported in parenthesis. The dependent variable is the standard deviation of the first-differenced goods price divided by the CPI. 
IFDP

Number
Author(s)

Charles Engel

John H. Rogers

Susanto Basu

John G. Fernald

Jaime Marquez

Gordon de Brouwer

Neil R. Ericsson

Marcus Miller

Lei Zhang

Guy V.G. Stevens

Peter Hooper

Elizabeth Vrankovich

Dale W. Henderson

Ning S. Zhu

of Nash Equilibrium: Macroeconomic and

Macroeconomic Examples

525 Targeting Inflation in the 1990s: Recent Challenges

524 Economic Development and Intergenerational Economic Mobility

523

Human Capital Accumulation. Fertility and Growth: A Re-Analysis

Richard T. Freeman Jonathan L. Willis

Murat F. Iyigun

Murat F. Iyigun

AlIan D. Brunner David P. Simon

Please address requests for copies to International Finance Discussion Papers, Division of International Finance, Stop 24, Board of Governors of the Federal Reserve System, Washington, DC 20551. 
Central Bank Independence, Inflation and Growth in Transition Economies

518 Alternative Approaches to Real Exchange Rates and Real Interest Rates: Three Up and Three Down

517 Product market competition and the impact of price uncertainty on investment: some evidence from U.S. manufacturing industries

$516 \quad$ Block Distributed Methods for Solving Multi-country Econometric Models

515 Supply-side sources of inflation: evidence from OECD countries

514 Capital Flight from the Countries in Transition: Some Theory and Empirical Evidence

513 Bank Lending and Economic Activity in Japan: Did "Financial Factors" Contribute to the Recent Downturn?

512 Evidence on Nominal Wage Rigidity From a Panel of U.S. Manufacturing Industries

511 Do Taxes Matter for Long-Run Growth?: Harberger's Superneutrality Conjecture

Options, Sunspots, and the Creation of Uncertainty Import Prices and the Competing Goods Effect
John Ammer

Allan D. Brunner

Prakash Loungani

Nathan Sheets

Hali J. Edison

William R. Melick

\section{Vivek Ghosal}

Prakash Loungani

Jon Faust

Ralph Tryon

Prakash Loungani Phillip Swagel

Nathan Sheets

Allan D. Brunner
Steven B. Kamin

Vivek Ghosal

Prakash Loungani

Enrique G. Mendoza Gian Maria Milesi-Ferretti

**Patrick Asea

David Bowman Jon Faust

Martin Uribe

Phillip Swagel

Enrique G. Mendoza

Linda L. Tesar 